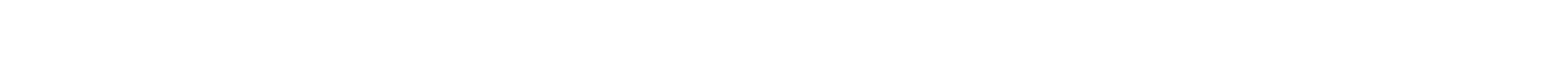

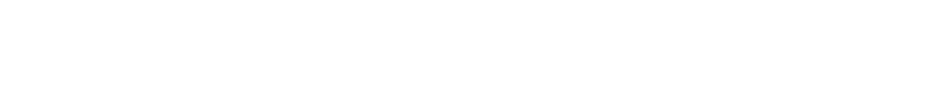

\author{
فك عبد الحائل خطلب الباغ \\ قصم علوم الحيلة \\ كلية العلوم \\ جلمعة الموط
}

(تاريخ الاستلام 31/ 3 / 2010 ؛ تاريخ القبول 7 /6 / 2010)

\section{الملإن}

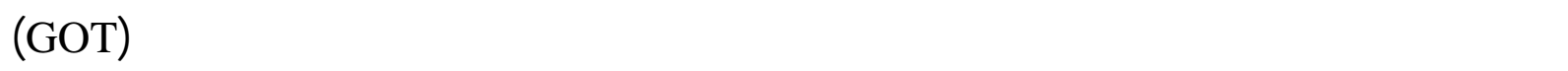

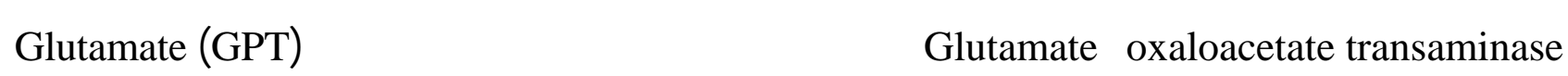

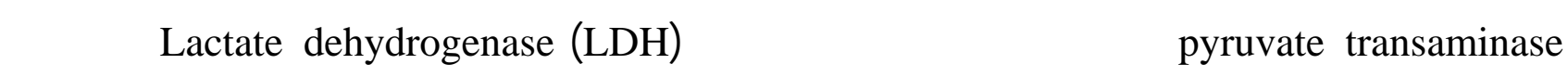

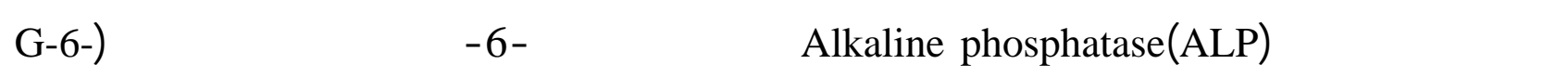
Glucose-6-phosphate dehydrogenase(PH Protoscoleces من الصل اغنلم ومقارينتهامع للسليمة وفي الرؤيست الاوليبة Echinocossus granulosus لمعرفة مدى تأثير الطفل على الانسجة القلبية للأغنلم.

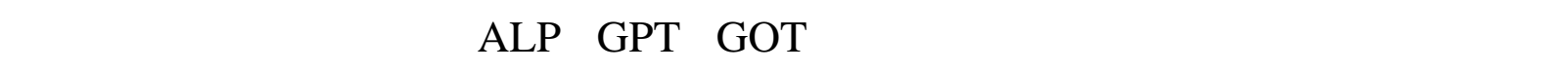

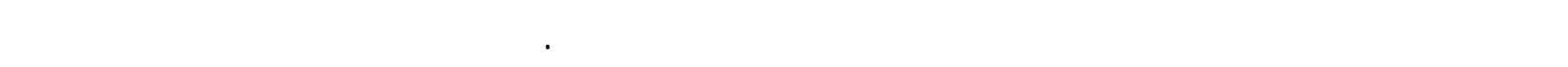

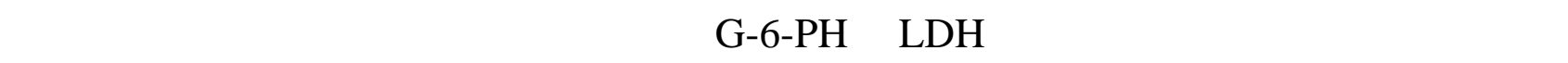
الحبيبية بالمقارنة مع الرؤيست الاولية والقلوب للسليمة. 


\title{
Determination of Activity of some Enzymes in Protoscoleces of Echinococcus granulosus of Sheep Origin and the Effect of Infection on the Enzymes Activity in Sheep Heart Tissues
}

\author{
Fulk A. Al-Dabbagh \\ Department of Biology \\ College of Scince \\ Mosul University
}

\begin{abstract}
The present study focused on comparision of the enzymes Glutamate oxaloacetate transaminase (GOT), Glutamate pyruvate transaminase (GPT), Lactate dehydrogenase (LDH), Alkaline phosohatase (ALP) and Glucose -6- phosphate dehydrogenase (G-66PH), in heart of sheep infected with Echinococcus granulosus of sheep origin, and those of noninfected sheep to clarify the effect of the parasite on heart tissues of sheep.

Results show a significant decrease in the activity of GOT, GPT and ALP in hearts of infected sheep compared with protoscoleces and control (non-infected) sheep. On the other hand, there seems to be a significant increase in activity of LDH and G-6-PH in hearts of infected sheep compared with protoscoleces and non-infected sheep.
\end{abstract}

